\title{
Epidemiology of cattle diseases in the northeast of La Pampa, Argentina
}

\author{
Miranda, A.O. \\ Instituto Nacional de Tecnología Agropecuaria (INTA), Estación \\ Experimental Anguil, CC 11, 6326 Anguil, La Pampa, Argentina. \\ Tel/Fax: +54-02954 495057. E-mail: miranda.ariel@inta.gob.ar
}

\begin{abstract}
Miranda, A.O.: Epidemiology of cattle diseases in the northeast of La Pampa, Argentina. Rev. vet. 25: 2, 81-86, 2014. A cross-sectional survey was carried out on 350 farms in the north east of La Pampa Province, Argentina. The goal was to record the prevalence of cattle diseases reported by farmers. Farms were stratified into three categories on the basis of adult herd size (300 to 500 cattle, 500 to 900 cattle and greater than 900 cattle) and a random sample selected from each strata. According to the productive system, farms were classified as fattening (F), cow-calf (C) and cow-calf-fattening (CF). Presented data are part of a comprehensive survey on cattle farms performed by INTA and Ministry of Production staff. The information described on this assay corresponds to principal signs and health problems recorded in different farms. Actinosis $(\mathrm{n}=115$ farms), bovine respiratory diseases (BRD) $(\mathrm{n}=77)$, neonatal calf diarrhea (NCD) $(\mathrm{n}=60)$, copper deficiency $(\mathrm{n}=54)$, and blackleg, gas gangrene and enterotoxaemia (BGE) $(n=39)$ were the main diseases. NCD and BGE were geographically distributed on the southern half area, while actinosis, copper deficiency and pneumonia were distributed on the central-west area. BRD also showed a second risk area on the northwest. According to production system, BRD was found to be associated to F, while $\mathrm{NCD}$, copper deficiency and BGE were associated to CF. According to strata level, no differences were found for any diseases considered for the present essay.
\end{abstract}

Key words: cattle, epidemiology, La Pampa, Argentina, diseases and risks mapping.

\begin{abstract}
Resumen
Miranda, A.O.: Epidemiología de enfermedades del bovino en el nordeste de La Pampa, Argentina. Rev. vet. 25: 2, 81-86, 2014. Un estudio de sección cruzada fue realizado en 350 establecimientos agropecuarios del nordeste de la Provincia de La Pampa, Argentina. El objetivo fue registrar la prevalencia de enfermedades en las majadas bovinas descriptas por los productores. Los establecimientos fueron estratificados en 3 categorías de acuerdo al tamaño de la majada (300 a 500 bovinos, 500 a 900 bovinos y más de 900 bovinos) seleccionando en forma aleatoria en cada estrato. De acuerdo al sistema productivo fueron clasificados en establecimientos de terminación, cría bovina y ciclo completo. Los datos presentados son parte de un estudio exhaustivo sobre establecimientos bovinos realizado por el INTA y el Ministerio de la Producción de la Provincia de La Pampa. La información detallada en este estudio corresponde a los principales signos clínicos y problemas sanitarios registrados por los productores. Un total de 115, 77, 60, 54 y 39 establecimientos reportaron actinosis, enfermedad respiratoria bovina (ERB), diarrea neonatal de los terneros (DNT), deficiencia de cobre (DC) y mancha, gangrena, enterotoxemia (MGE) como principal enfermedad, respectivamente. DNT y MGE estuvieron geográficamente distribuidas en la mitad sur del área de estudio, mientras que actinosis, DC y ERB se presentaron distribuidas sobre el centro oeste del área. ERB también mostró una segunda área de riesgo sobre el noroeste de la región. De acuerdo al sistema productivo las ERB estuvieron asociadas a establecimientos de terminación mientras que las DNT y MGE a establecimientos de ciclo completo. No se asoció ninguna enfermedad descripta al tamaño de la majada en el presente trabajo.
\end{abstract}

Palabras clave: bovino, epidemiología, La Pampa, Argentina, cartografía de enfermedades y riesgos. 


\section{INTRODUCTION}

Animal health is one of the many factors that conspire against productivity of cattle production systems. The development of health information systems, together with other aspects regarding animal production, aid in the use and interpretation of data for efficient planning and livestock policy management. There are many countries around the world where geographic information systems (GIS) ${ }^{2}$ detect diseases, trends or productive problems as well as prevalence of pathologies in order to make rational decisions.

Some states from the United States of North America ${ }^{4}$ have developed the National Animal Health Monitoring System (NAHMS) which uses productive, economic and sanitary data gathered from cattle production. Several European countries ${ }^{6,8}$ are pioneers in this type of information scrutiny as well as the development of software that allows to perform analysis of risk, costbenefit relationship, and policy address.

Exploratory maps help researchers to have a better understanding of the geographic distribution of diseases for defining spatial risk ${ }^{1}$. In Argentina and other countries of South America the implementation of databases and sanitary information systems is just beginning. These systems will help to determine cattle disease prevalence and to identify possible risk factors for better control strategies.

The aim of this assay was to describe, characterize and analyze the principal cattle diseases affecting herds in the northeast of La Pampa using data gathered from a field survey.

\section{MATERIAL AND METHODS}

Geographic area and population survey. This was a cross sectional survey of health management practices and prevalence diseases. The sampling frame comprised farms from Chapaleufú, Realicó, Rancul, Trenel, Maracó, Conhelo, Capital, Quemú Quemú, Catriló and Atreucó, located in the north-east of La Pampa Province, Argentina (Figure 1). For the survey, only those farmers owing more than 300 bovines were considered. A total of 350 farmers were surveyed and stratified into three strata on the basis of herd size: small (S) (300 to 500 animals), medium (M) (500 to 900) and large (L) (more than 900). To determine the number of farms by strata and district, a finite population sampling method ${ }^{3}$ was used. A confidence level of $5 \%$ was established. After defining the number of farms, random sampling from the list of farmers was used to pick the farms to survey within each stratum. Selected farms were visited by INTA and Ministry of Production staff.

Survey design. A cross-sectional survey of health management practice with reference to spatial location and productive information (stock farmer, livestock hectare, principal activity) and sanitary information such as vaccinations, frequency of diseases (venereal,

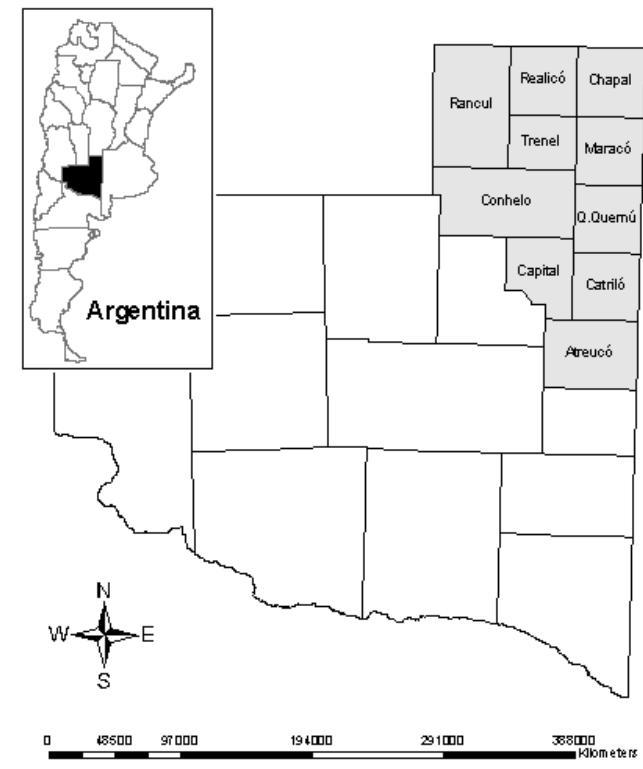

Figure 1. Map of La Pampa Province showing the location of the area of study.

endoparasite, ectoparasite, horn fly, myiasis, bloat, tetany down cows and keratoconjuntivitis) was conducted. Furthermore, the survey included questions regarding clinical signs and presence or not of diseases in each farm. For the latter, not only a list of signs and symptoms but also a disease list was provided. Morbidity and mortality, category affected, and season of the year, were recorded. Finally, confirmation of diseases by means of clinical observation or laboratory tests was considered.

Mapping and statistics analysis. Farm identifiers were matched with a digital map of farm boundaries and the location point of each farm was defined as the centroid by means of Arcgis software 9. The outcome geographical representation showed the risk of the area under study. However, the spatial point data is generally irregular as well as discretely geo-referenced in space and therefore requires spatial interpolation for mapping isopleths. Geostatistical kriging method was chosen and provided by ArcGis 9 (ESRI). On the other hand, to detect clusters, statistical spatial software SaTScan (v. 7.0.3) was used, considering the presence (1) or absence (0) of disease as qualitative and quantitative variable of analysis, respectively.

Risk factors inside and outside the cluster. Each disease was considered as a cluster and subjected to spatial statistical analysis for determining high prevalence areas. It was inferred that the spatial location of farms would have conditioned the presence or absence of diseases, based on productive and agro-ecological features of the region such as: productive activity (livestock, agricultural and combination), productive system (CF, $\mathrm{F}$ and $\mathrm{C}$ ) and stocking rate. For the statistical analysis both descriptive and association measures techniques provided by Infostat statistic software were used ${ }^{5}$. 


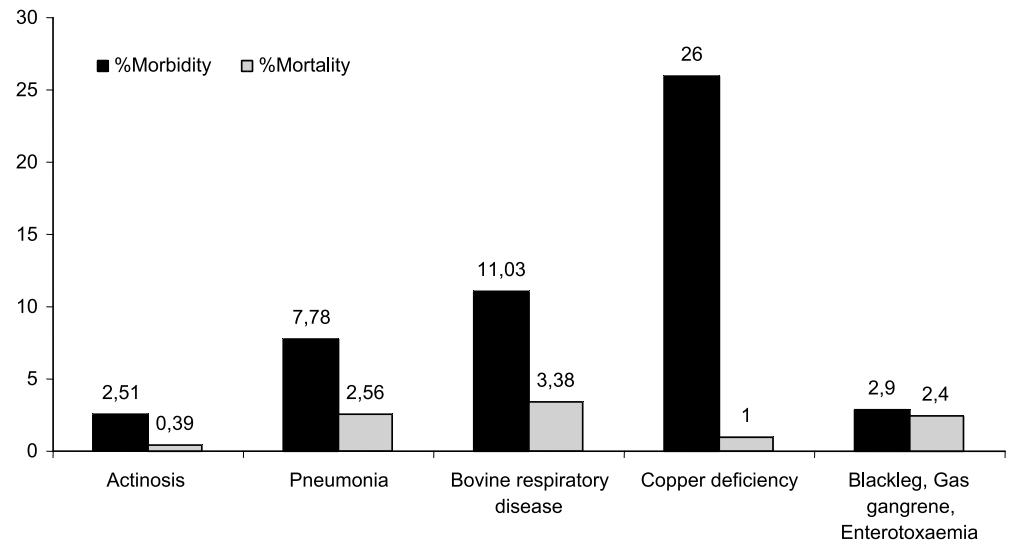

Figure 2. Percentage of morbidity and mortality of the main diseases.

Parasitic diseases were not considered for this assay.

Actinosis: an important number of farms $(n=115)$ with actinosis were recorded, having low morbidity and mortality rates (Figure 3). Principal signs were jaw abscess $(21.7 \%)$, swollen throat and wooden tongue $(28.0 \%)$ which were easy to identify by farmers and for this reason only $52 \%$ requested veterinary diagnose. Eleven percent of farmers reported both diseases affecting animals at the same time. The major prevalence on the departments of the middle area on isopleths risk map-

\section{RESULTS}

Three hundred and fifty farms conforming 378,748 hectares (mean: 1,091 $\pm 1,930 \mathrm{ha}$ ) and having 327,993 animals (mean: $937 \pm 1,001)$ were considered. A total of 67 (S), 112 (M) and 147 (L) farms were surveyed, being most of them a combination of cow-calf-fattening ( $\mathrm{n}=226 ; 63 \%)$. Remaining farms were either fattening $(n=106 ; 33 \%)$ or cow-calf $(n=14 ; 4 \%)$. Median stocking density was 1.12 head per hectare (range \pm 0.54 ).

As a result of disease signs and health problems observed during the survey, five main pathologies were described: actinosis (actinomycosis / actinobacillosis), bovine respiratory diseases (BRD), neonatal calf diarrhea (NCD), copper deficiency and black leg, gas gangrene and enterotoxaemia (BGE). Figure 2 shows the morbidity and mortality percentages of each disease.

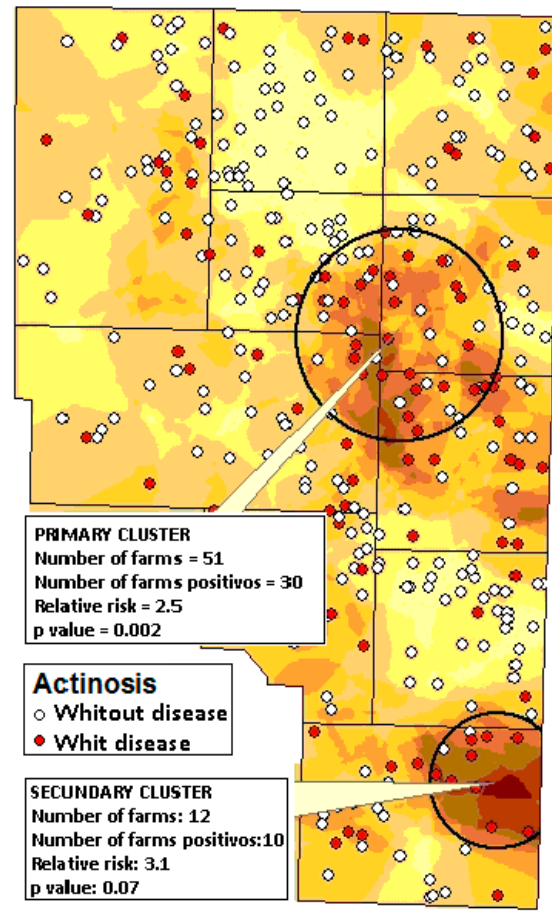

Figure 3. Isopleth risk map for actinosis. Primary and secondary clusters showing details regarding farm number, relative risk and statistic likelihood. ping is shown in Figure 3. Mapping shows two clusters, the primary cluster had a relative risk (RR) of $2.5(0.95$; $\mathrm{p}=0.002)$ and the secondary cluster a RR of $3.1(0.90$; $\mathrm{p}=0.07)$. No statistical differences were found regarding risk factor analysis.

Bovine respiratory diseases (BRD): cases with respiratory symptomatology such as colds $(7.4 \%)$, coughs $(16.9 \%)$, bronchopneumonia $(20.7 \%)$, fever and weakness $(5.7 \%)$ in 77 herds, were recorded. Calves $(72 \%)$ and steers $(17 \%)$ were affected during weaning on autumn (44\%) and winter (45\%). Furthermore, 3.4\% (F $3.6 \%$; CF $3.3 \%$ ) of farmers reported fever, cough and stress after transportation. The mapping risk shows two clusters (Figure 4), the primary having a RR of 4.8 $(0.95 ; p=0.01)$ and the secondary a RR of $3.18(0.95$; $\mathrm{p}=0.008)$. Regarding cluster factor risk, BRD was sta-

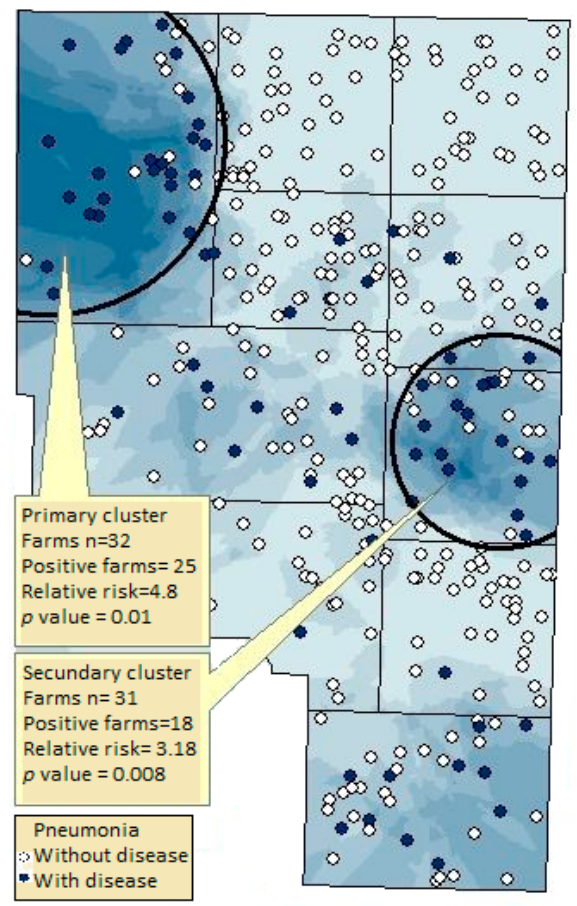

Figure 4. Isopleth risk map of BRD. Primary and secondary clusters showing details of farm number, relative risk and statistic likelihood. 


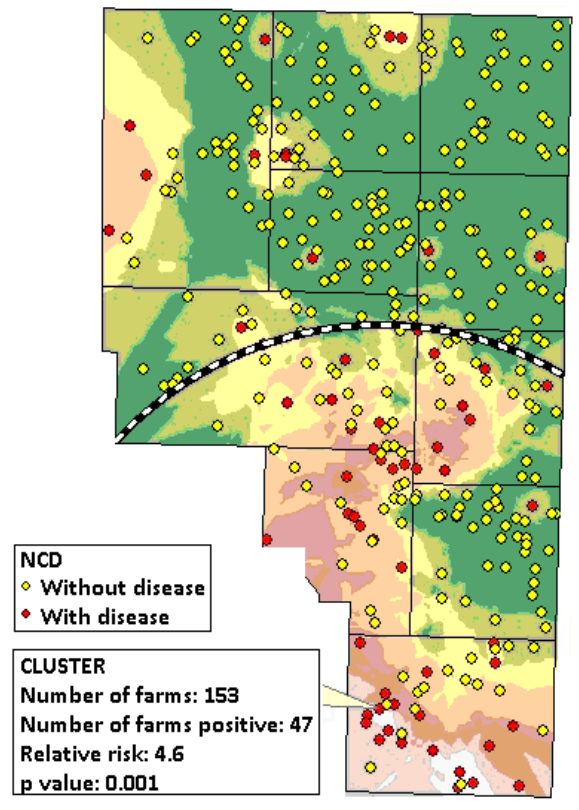

Figure 5. Isopleth risk map of NCD. Cluster with details of farm number, relative risk, and statistic likelihood.

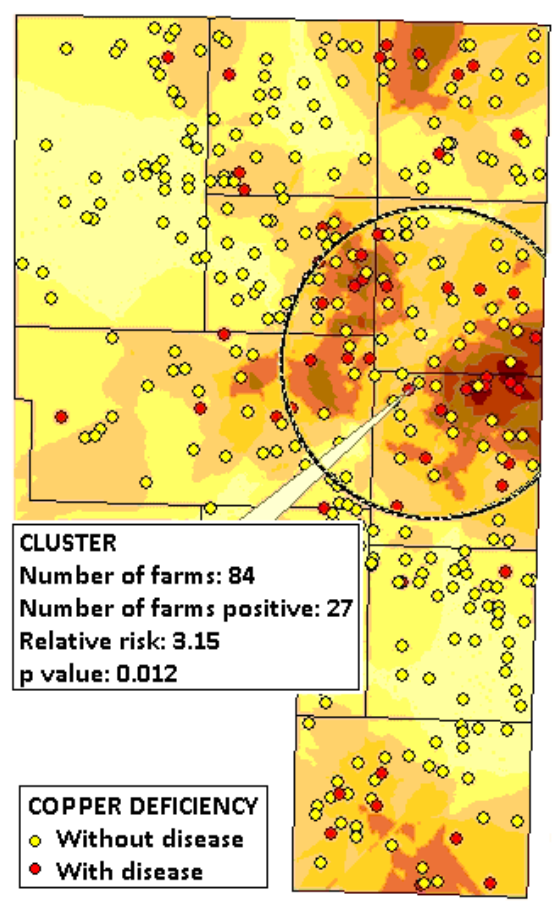

Figure 6. Isopleth risk map of copper deficiency. Cluster with details of farm number, relative risk, and statistic likelihood.

tistically associated with fattening systems (odds ratio $\mathrm{OR}=1.76 ; \mathrm{p}=0.051$ ).

Neonatal calf diarrhoea (NCD): twenty five percent $(n=60)$ of farmers (239) having cows and bulls reported not only problems of watery faeces and colitis in one to two week old calves but also pneumoenteritis $(21.8 \%, \mathrm{n}=52)$. Figure 5 shows the RR of $\mathrm{NCD}$, where

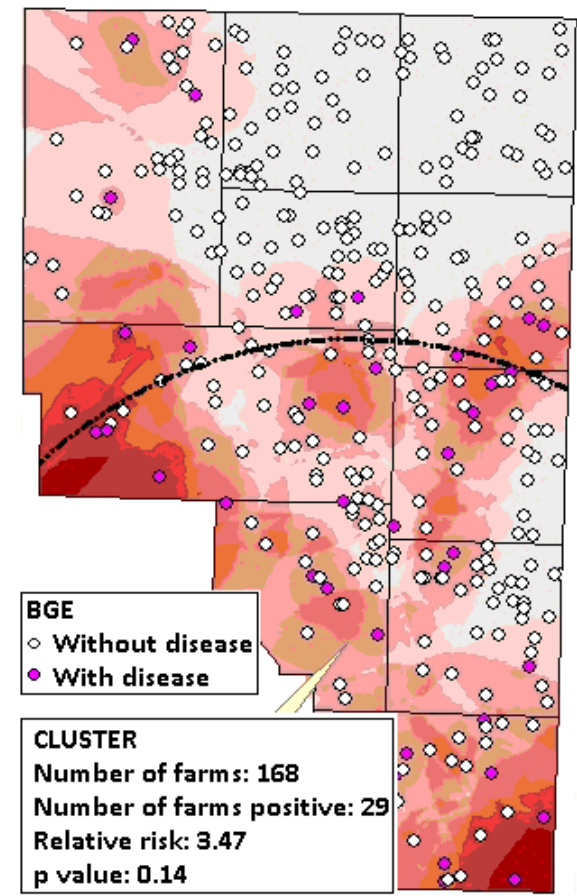

Figure 7. Isopleth risk map of BGE. Cluster with details of farm number, relative risk, and statistic likelihood.

two areas with different epidemiological features can be seen. The north area does not have risk, while the south area shows a RR of $4.6(0.95 ; p=0.001)$. Production system characteristics of the southern area show a majority of $\mathrm{CF}$ and $\mathrm{C}$ productive systems in concordance with the outcome on the risk factor study $(p=0.022 ; O R=1.74)$. No statistical differences were found between strata.

Copper deficiency: farmers reported copper deficiency problems $(\mathrm{n}=54,15 \%)$. Figure 6 shows a cluster on central east area with a RR of $3.15(0.95$; $\mathrm{p}=0.012$ ). On the other hand, the majority of cases $\left(\mathrm{X}^{2} 4.48 ; \mathrm{p}=0.04\right)$ were present in $\mathrm{CF}$ farms. Livestock systems showed higher risk of copper deficiency presence $(\mathrm{p}=0.065 ; \mathrm{OR}=1.74)$ than agriculture-livestock systems. Veterinary diagnostics revealed that copper deficiency affected all categories: calves (34\%), cows $(18 \%)$ and heifers, steers and bulls (10\%).

Black leg, gas gangrene and enterotoxaemia (BGE): owners reported sudden dead $(\mathrm{n}=39,11 \%)$, maimed animals or feeding abrupt changes as signs of black leg and gas gangrene, respectively $(16.3 \% \mathrm{CF}$; $4.5 \% \mathrm{~F})$ and enterotoxaemia (3.3\% CF; 2.7\% F). More cases of black leg or gas gangrene in CF farms $\left(\mathrm{X}^{2} 9.7\right.$; $\mathrm{p}=<0.002)$ were observed, mainly affecting calf $(87 \%)$ and baby beef (11\%). The morbidity and mortality were $2.9 \%$ and $2.5 \%$, respectively. In general, owners reported veterinary diagnose $(77 \%)$. Almost the total of the surveyed farmers $(n=338,98 \%)$ performed vaccination against BGE. The mean number of annual doses was 
$1.47 \pm 0.59$, with $58 \%, 37 \%$ and $4.8 \%$ of farmers administering one, two and three doses per year, respectively. Figure 7 shows the risk of distribution of BGE with a major presence of cases on the middle south area with a RR of $3.47(0.95 ; \mathrm{p}=<0.001)$.

\section{DISCUSSION}

Considering the epidemiological-productive point of view, diseases showed different behaviour. Copper deficiency showed high morbidity $(26 \%)$ and low mortality (1\%), while NCD showed low morbidity $(11.03 \%)$ but high mortality (3.38\%). This feature often puzzles farmers, who underestimate subclinical losses for those diseases with low mortality. The results found in this study regarding morbidity and mortality of diseases were consistent with those found by the Regional Unit of Diagnostic Casuistic of INTA (National Institute of Agricultural Technology) (unpublished observations).

Actinosis: two diseases were considered under this denomination: actinomycosis (Actinomyces bovis) and actinobacillosis (Actinobacillus lignieresii). Both have similar clinical characteristics and treatments. Considering practical aspects, the exact location of the injury will help for the final diagnose, but the identification of the etiologic agent by means of bacterial culture is still the most accurate determination. Steers of 1.5 to 2 years old that are changing teeth are considered at risk and this characteristic agrees with the results obtained in our study, where steers $(50 \%)$ and yearlings $(22 \%)$ were the main affected categories. No differences were observed when considering productive system. Both etiological agents are present in the oral cavity, which invade deep tissues (jaw, tongue, lymph nodes of the head, neck and thorax) after traumatic injuries (e.g. abrasive grass) or by unknown mechanisms ${ }^{7}$. The occurrence of diseases depends on individual condition; this would explain the lack of association with stocking rate and productive strata.

BRD: under this name a set of common diseases, signs and symptoms that affect young categories are commonly known as pneumonia. The economics losses caused by BRD (delayed growth, high mortality, reduced fertility and high treatment costs) have been studied with more detail for intensive productive systems (dairy farms and feedlots) ${ }^{13,14}$ rather than the grazing or semi-intensive systems. According to our results, looses are greater for both grazing and semi-intensive systems. On the other hand, the productive feature of these systems -grazing feeding with low crowdingwould explain the lack of difference regarding stocking rate. BRD is present in fattening farms where calves are weaned in autumn and winter and is associated to environmental factors, such as low temperatures and host immunosuppressive condition. Despite being a well known disease by farmers, only $28.6 \%(n=100)$ use vaccination to prevent it. Furthermore, only $42 \%$ of the farmers use a second dose of the vaccine, although laboratories recommend a re-vaccination 20 to 30 days after the first one ${ }^{11}$. No differences were found regarding productive system.

NCD: results showed positive association $(\mathrm{p}=0.022$; $\mathrm{OR}=1.74$ ) between $\mathrm{NCD}$ and $\mathrm{CF}$ and $\mathrm{C}$ systems but no differences regarding productive strata and stocking rate. White to light yellow watery faeces with bad odour were observed on 30 days-old calves. Multiple etiologic factors (Rotavirus, Coronavirus, Escherichia coli, Salmonella sp. and others) cause digestive symptoms with respiratory complications caused by Pasteurella sp, Parainfluenza 3, and others. This kind of presentation has been referred as pneumoenteritis ${ }^{12}$. In our assay $21.8 \%$ of the farmers referred calves to have pneumoenteritis. This condition occurs during the first days of life and for this reason prevention is essential by vaccination of females (cows and heifers during the last month of pregnancy) as immunity is guaranteed by colostrum. Although farmers $(16.5 \%)$ reported the use of preventive vaccines, many of them (68\%) did not repeat the second dose 30 days after, despite laboratory specifications that recommends for pregnant heifers and unvaccinated cows two doses with an interval of 15 to 30 days ${ }^{11}$. A probable reason for the latter is that farmers reduce management practices when cows are at the end of pregnancy.

Copper deficiency: this pathology can be produced by insufficient amount of copper on the diet or excess of molybdenum or sulphates in the feeding or drinking water. Both cases have been reported in La Pampa Province with excess of molybdenum being the main cause ${ }^{9}$. Young cattle ( 2 or 3 months) are more susceptible to copper deficiency, especially suckling calves with cows receiving insufficient copper in their diet ${ }^{10}$. This description agrees with the results found in our survey, where calves had the higher prevalence. Although copper deficiency was described in all categories, suckling calf, cows and heifers were the affected categories and this can be associated to CF. As regards to stocking rate, no differences were found and this could be explained because this disease is not associated with crowding.

$\boldsymbol{B G E}$ : cases of mortality produced by different etiologic agents (Clostridium septicum, C. chauvoei, C. perfringens, C. sordellii and C. Novyi) were frequently reported by owners although an important number of them vaccinated herds as prevention. This could be due to the low percentage of farmers (37\%) re-vaccinating livestock after 20 to 30 days after the first application (label laboratory specifications) or lack of immunity response from commercial vaccines. BGE were described mainly in calves and this can be related to CF. No differences were found regarding stocking rate, probably because most of the surveyed farms corresponded to semi-intensive production systems. 
We did not find differences regarding productive strata for any disease. This is probably due to the number of heads (more than 300) of the surveyed farms. This situation probably would have changed if we would have select small-scale farmers, but this was not the objective of this epidemiological study.

It is concluded that results give useful epidemiological information regarding several important diseases for the north-east of La Pampa Province and offer valuable data about risk distribution of these diseases. Results also help to make better decisions or to develop future studies to improve the competitiveness of meat production systems.

Acknowledgements. The author thanks farmers and veterinarians for the unselfish collaboration. Also to the Minister of Production, Government of La Pampa Province and National Institute of Agricultural Technology (INTA) for the funds.

\section{REFERENCES}

1. Berke O. 2005. Exploratory spatial relative risk mapping. Prev Vet Med 71: 173-182.

2. Bosque Sendra J. 2000. Sistemas de información geográfica, $2^{\text {nd }}$ ed., Rialp, Madrid, $453 \mathrm{p}$.

3. Cochran WG. 1997. Técnicas de muestreo, CECSA, México, $513 \mathrm{p}$.

4. Curtis CR, Farrar JA. 1990. National animal health monitoring system in the United States. Prev Vet Med 8: 87-225.

5. Di Rienzo JA, Casanoves F, Balzarini MG, Gonzalez L, Tablada M, Robledo CW. 2010. InfoStat V. 2010. Grupo InfoStat, FCA, Univ. Nac. Córdoba, Argentina.
6. Frankena K, Noordhuizen JP, Willeberg P, van Voorhuysen PF, Goelema JO. 1990. Episcope, computer programs in veterinary epidemiology. Vet Rec 9: 573-576.

7. Jones TC, Hunt RD, King NW. 1997. Veterinary Pathology, $6^{\text {th }}$ ed., Williams \& Wilkins, Baltimore, $1392 \mathrm{p}$.

8. Morris RS, Sanson RL, McKenzie JS, Marsh WE. 1993. Decision support systems in animal health. Proceedings of the Society for Veterinary Epidemiology and Preventive Medicine, Exeter (UK): 188-199.

9. Pechin G, Cseh S, Corbellini C, Idiart J, Moralejo R, Visconti M, Drake M, Yarrar M. 1995. Estudio de la deficiencia mineral en bovinos de carne en el Departamento Maracó, La Pampa, Argentina. Rev Arg Prod Anim 15: 492-494.

10. Radostits OM, Gay CC, Blood DC, Hinchcliff KW. 2002. Medicina Veterinaria, tratado de las enfermedades del ganado bovino, ovino, porcino, caprino y equino, $9^{\circ}$ ed., McGraw-Hill, Barcelona, p. 1766-1784.

11. Suárez VH et al. (12 autores). 2006. Características del manejo sanitario en el este de la Provincia de La Pampa, Argentina. Boletín Divulg Técn INTA Anguil (La Pampa, Argentina), 90: 111.

12. Suárez VH et al. (14 autores). 2008. Prevalencia de patologías e incidencia de la sanidad en los sistemas bovinos en el este de la Provincia de La Pampa, Argentina. Vet Arg 25: 258-280.

13. Snowder GD, Van Vleck LD, Cundiff LV, Bennett GL. 2006. Bovine respiratory disease in feedlot cattle: Environmental, genetic, and economic factors. J Anim Sci 84: 1999-2008.

14. Van der Fels-Klerx HJ, Sorensen JT, Jalvingh AW, Huirne RB. 2001. An economic model to calculate farmspecific losses due to bovine respiratory disease in dairy heifers. Prev Vet Med 51: 75-94.

\section{Dr. Juan José Brem}

Luego de doce años de desempeñarse como Administrador (ad honorem) de "Revista Veterinaria" se produjo el alejamiento del Dr. Juan José Brem. Quienes integramos el cuerpo editorial de la publicación oficial de la Facultad de Ciencias Veterinarias de la UNNE le hacemos llegar nuestro reconocimiento por la eficiente tarea realizada durante el lapso 2003-2014. 